\title{
Constitutive Activation of the Gastrin-releasing Peptide Receptor Expressed by the Nonmalignant Human Colon Epithelial Cell Line NCM460
}

\author{
Heather A. Ferris, ${ }^{\star}$ Robert E. Carroll,, Mark M. Rasenick, ${ }^{\ddagger}$ Richard V. Benya ${ }^{\star}$ \\ $*$ Department of Medicine and ${ }^{\ddagger}$ Department of Physiology and Biophysics and of Psychiatry, University of Illinois at Chicago, Chicago, \\ Illinois 60612; and the Chicago Veterans Administration Medical Center (West Side Division), Chicago, Illinois 60612
}

\begin{abstract}
Gastrin-releasing peptide (GRP) causes multiple effects in humans by activating a specific heptaspanning receptor. Within the gastrointestinal tract, GRP receptors (GRP-R) are not normally expressed by mucosal epithelial cells except for those lining the gastric antrum. In contrast, recent studies have shown that up to $40 \%$ of resected colon cancers aberrantly express this receptor. This is important because the GRP-R can cause the proliferation of many, but not all, tissues in which it is expressed. Since GRP and other agonists are not known to exist in the colonic lumen, it has not been clear how or even if GRP-R expression in colon cancer contributes to cell proliferation. To evaluate the functional consequence of GRP-R expression on colonic epithelium, we transfected the recently isolated nonmalignant human colon epithelial cell line NCM460 with the cDNA for this receptor. All NCM460 cell lines expressing varying numbers of GRP-R bound selected agonists and antagonists indistinguishably from receptors expressed by other human tissues. Furthermore GRP-R-expressing transfected cell lines, but not wild-type NCM460 cells, proliferated independently of serum or other growth factors. Further evaluation revealed that GRP-R in these cells tonically stimulated G $\alpha q / 11$, resulting in increased phospholipase $\mathrm{C}$ activation. Since transfected cells do not secrete GRP, nor is their growth influenced by exposure to receptor-specific antagonists, these data indicate that GRP-R ectopically expressed by NCM460 cells are constitutively active. This report provides the first evidence of mutation-independent heptaspanning receptor constitutive activation resulting in cell proliferation, and identifies a potential mechanism whereby the GRP-R may act as an oncogene in human colon cancer. (J. Clin. Invest. 1997. 100: 2530-2537.) Key words: bombesin $•$ cancer $•$ colon $• \mathrm{G}$ proteins
\end{abstract}

\section{Introduction}

Gastrin-releasing peptide (GRP) $)^{1}$ is the mammalian homologue of bombesin, a neuropeptide with diverse effects in the

Address correspondence to Richard Benya, Department of Medicine, University of Illinois at Chicago, 840 South Wood Street (M/C 787), Chicago, IL 60612. Phone: 312-666-6500 ext. 3439; FAX: 312455-5877; E-mail: rvbenya@uic.edu

Received for publication 2 April 1997 and accepted in revised form 11 September 1997.

The Journal of Clinical Investigation

Volume 100, Number 10, November 1997, 2530-2537

http://www.jci.org central nervous, immune, pulmonary, and gastrointestinal (GI) systems. GRP binds to and activates a specific receptor which is a member of the seven transmembrane-spanning, $G$ protein-coupled receptor superfamily (1-3). In the GI tract, GRP receptors (GRP-R) are expressed by the myenteric and submucosal neural plexuses innervating the underlying smooth muscle, where they act to modulate intestinal contractility and transit $(4,5)$. In mice $(6)$, pigs $(7,8)$, rats, guinea pigs, and chickens $(9,10)$, GRP-R also are expressed by mucosal epithelial cells lining the GI tract. In contrast, a recent study indicates that human GI epithelial GRP-R expression is limited to cells overlying the gastric antrum (11). Thus the expression of GRP-R by nonantral GI tract tumors in humans, as is observed in colon cancer, must be considered abnormal.

It recently has been observed that $24 \%$ (12) to $40 \%$ (13) of surgically resected colon cancers aberrantly express GRP-R. Furthermore, this receptor is associated with the proliferation of all human colon cancer cell lines in which it is expressed (14-17). Yet little is known about the mechanism(s) whereby this receptor can cause the proliferation of human colon cancers. In many other human cancers GRP can act as a mitogen including adenocarcinoma cell lines of the breast (18) and prostate $(19,20)$, as well as in all small cell lung cancer cell lines studied to date $(21,22)$. In small cell lung cancer, tumor cells express GRP-R and secrete GRP, allowing this peptide to act as an autocrine growth factor (21). Unfortunately, little is known about the mechanisms whereby the GRP-R can cause cell proliferation in other tumors including those arising from the colon. Indeed, it has not even been possible to determine if the GRP-R plays a critical role in colon cancer proliferation, or if its expression merely represents an epiphenomenon.

In this study we present evidence to suggest that when the nonmutated wild-type GRP-R is aberrantly expressed by human colonocytes it becomes constitutively activated. To demonstrate this phenomenon, we studied the recently isolated nonmalignant human colon epithelial cell line NCM460 (23), and which like native colonic epithelia do not normally express GRP-R (11). We herein show that ectopic expression of the human GRP-R by NCM460 cells results in constitutive activation of this receptor, thereby allowing transfected cells to proliferate independently of serum and growth factors. These findings demonstrate a possible mechanism for GRP-Rinduced proliferation of human colon cancers, and suggests the

1. Abbreviations used in this paper: AAGTP, $\mathrm{P}^{3}$ (4-azidoanilido)$\mathrm{P}^{1}$-guanosine $5^{\prime}$-triphosphate; GRP, gastrin-releasing peptide; GRP-R, GRP receptor; GI, gastrointestinal; NCM460-HIGH and -LOW, NCM460 cells expressing high and low numbers of GRP-R, respectively; NCM460-GAL, cells expressing the galanin receptor; NCM460VECTOR, cells transfected only with vector pcDNA-3. 
possibility that this receptor protein may behave as an oncogene.

\section{Methods}

Reagents. Ham's F-12 media, fetal bovine serum, and aminoglycoside G-418 were from Gibco/BRL (Waltham, MA). Bovine serum albumin (fraction V) and Hepes were obtained from Boehringer Mannheim Biochemical (Indianapolis, IN); insulin, hydrocortisone, glutamine, selenium, transferrin, soybean trypsin inhibitor, EGTA, trypsin, and bacitracin were obtained from Sigma Chemical Co. (St. Louis, MO); bombesin, GRP, and neuromedin B (NMB) were obtained from Peninsula Laboratories (Belmont, CA); Dowex AG 1-X8 anion exchange resin (100-200 mesh, formate form) was from Bio-Rad (Richmond, CA); Hydro-Fluor scintillation fluid, methanol and hydrochloric acid were from the J.T. Baker Chemical Co. (Phillipsburg, NJ); myo- $\left[2-{ }^{3} \mathrm{H}\right]$ inositol $(16-20 \mathrm{Ci} / \mathrm{mmol})$ and $\left[{ }^{3} \mathrm{H}\right.$-methyl]thymidine were from Amersham Life Science (Arlington Heights, IL). NCI-H128 cells were obtained from ATCC (Rockville, MD) while NCM460 cells were provided by Dr. M.P. Moyer (University of Texas, San Antonio, TX) (23). [ $\left.{ }^{125} \mathrm{I}-\mathrm{Tyr}^{4}\right]$ bombesin and the antagonists [D-Phe ${ }^{6} \mathrm{Leu}^{13}$ $\left.(\psi 13-14) \mathrm{CPA}^{14}\right]$ bombesin $(6-14)$ and D-Phe ${ }^{6}$-bomesin methyl ester were provided by Dr. R.T. Jensen (NIDDK; National Institutes of Health, Bethesda, MD); the antibody to G $\alpha \mathrm{q} / 11$ (number 0945) was provided by Dr. D.R. Manning (University of Pennsylvania, Philadelphia, PA) (24); while the human GRP receptor cDNA was provided by Dr. J.F. Battey (NIDCD National Institutes of Health) (3).

Creation of GRP receptor-expressing NCM460 cell lines. NCM460 cells were stably transfected using a full length human GRP receptor cDNA clone expressed in pcDNA-3 (Invitrogen Corp., Carlsbad, CA) using calcium phosphate precipitation as previously described (11). All transfected cell lines were maintained in media optimized to support colonocyte explants (Ham's F-12 supplemented with $0.5 \mathrm{U} / \mathrm{ml}$ insulin, $0.4 \mu \mathrm{g} / \mathrm{ml}$ hydrocortisone, $0.58 \mu \mathrm{g} / \mathrm{ml}$ glutamine, and $20 \%$ fetal bovine serum) (25) additionally containing 280 $\mu \mathrm{g} / \mathrm{ml}$ aminoglycoside G-418; whereas wild-type NCM460 cells were maintained in colonocyte media without aminoglycoside G-418. Cells were passaged every $8-10 \mathrm{~d}$ by mechanical disaggregation. Two different stably transfected GRP-R-expressing NCM460 cell lines were evaluated, NCM460-HIGH with $\sim 5,000$ binding sites per cell, and NCM460-LOW, with $\sim 2,100$ binding sites per cell (originally identified as clones \#7 and \#5, respectively, in reference 11).

Creation of control NCM460 cell lines. (a) To test the specificity of GRP-R expression on NCM460 cell behavior, we also created a stable cell line expressing the human galanin-1 receptor. The cDNA for the galanin-1 receptor was cloned from human small intestine as originally described in (26). NCM460 cells were transfected using this cDNA subcloned into the expression vector pcDNA-3, and stable clones were selected in the presence of aminoglycoside G-418 as described above. A cell line expressing 5,700 \pm 480 galanin binding sites per cell, similar in number to that of cell line NCM460-HIGH, was named NCM460-GAL and retained for evaluation. $(b)$ To test whether the vector pcDNA-3 alone could be influencing cell behavior, a fourth and final cell line identified as NCM460-VECTOR was created. NCM460 cells were treated with insert-less pcDNA-3 vector as described above. Cell lines resistant to aminoglycoside G-418 were then screened by Southern analysis using a pcDNA-3 probe, and the cell line with the strongest signal for pcDNA-3 (NCM460-VECTOR) was selected and used for further evaluation.

Binding studies. Mechanically disaggregated cells were resuspended in binding buffer $(120 \mathrm{mM} \mathrm{NaCl}, 72 \mathrm{mM} \mathrm{KCl}, 6.0 \mathrm{mM}$ pyruvate, $7.1 \mathrm{mM}$ fumarate, $6.0 \mathrm{mM}$ glutamate, $14 \mathrm{mM}$ glucose, $0.01 \%$ soybean trypsin inhibitor, $154 \mathrm{mM}$ Hepes, $217 \mathrm{mM} \mathrm{KH}_{2} \mathrm{PO}_{4}, 120 \mathrm{mM}$ $\mathrm{MgCl}_{2}, 100 \mathrm{mM} \mathrm{CaCl}, 0.2 \%$ bovine serum albumin, and $0.1 \%$ bacitracin $[\mathrm{pH} 7.5])$. Incubations contained $75 \mathrm{pM}\left[{ }^{125} \mathrm{I}_{-} \mathrm{Tyr}^{4}\right]$ bombesin and $3 \times 10^{6} \mathrm{cells} / \mathrm{ml}$ for various times at defined temperatures. Nonsaturable binding of $\left[{ }^{125} \mathrm{I}_{-} \mathrm{Tyr}^{4}\right]$ bombesin was the amount of cell-asso- ciated radioactivity when the incubation mixture contained $1 \mu \mathrm{M}$ bombesin. Nonsaturable binding was $<10 \%$ of total binding in all experiments, with all values in this paper reported as saturable binding (i.e., total minus nonsaturable binding).

Cell proliferation assays. (a) All cell lines so evaluated were mechanically disaggregated, resuspended in either Ham's F-12 alone or in colonocyte media, and plated at a concentration of 50,000 cells $/ 500 \mu \mathrm{l}$ in 24-well tissue culture plates. After exposing cells at the indicated time points to $1 \mathrm{mM}$ EDTA in $1 \%$ trypsin for $2 \mathrm{~min}$, cells were counted using a Bright-Line hemacytometer (Cambridge Instruments, Buffalo, NY) in octuplicate. (b) Cell proliferation also was determined by measuring $\left[{ }^{3} \mathrm{H}\right.$-methyl]thymidine incorporation as previously described $(27,28)$. Briefly, mechanically disaggregated cells were plated at a concentration of 50,000 cells/well in 24-well tissue culture trays. After $16 \mathrm{~h}$ (overnight) to allow for cell attachment, colonocyte media was replaced with Ham's F-12 alone for $7 \mathrm{~d}$. During the final $8 \mathrm{~h}$ of incubation $1 \mu \mathrm{Ci} / \mathrm{ml}\left[{ }^{3} \mathrm{H}\right.$-methyl]thymidine was added with or without selected peptides. Cell monolayers were washed three times in ice-cold PBS, detached using $0.1 \%$ trypsin in $1 \mathrm{mM}$ EDTA, and the radioactivity of DNA precipitable in $10 \%$ trichloroacetic acid determined.

Reverse transcriptase-PCR (RT-PCR). Cells were grown to nearconfluence, and then washed twice in PBS. Cells were lysed in situ using guanidium isothiocyanate, and the total RNA extracted according to the method of Chomczynski and Sacchi (29). RT-PCR was performed using $10 \mu \mathrm{g}$ RNA using murine maloney reverse transcriptase (Gibco/BRL) and random hexamers. PCR conditions were $94^{\circ} \mathrm{C}$ for $30 \mathrm{~s}, 56^{\circ} \mathrm{C}$ for $30 \mathrm{~s}$, and $72^{\circ} \mathrm{C}$ for $1 \mathrm{~min}$ for 35 cycles using 16:1 AmpliTaq (Perkin-Elmer Corp., Foster City, CA) and Pfu (Stratagene, Inc., La Jolla, CA) polymerases in a reaction mixture containing $6 \%$ glyc$\operatorname{erol}(\mathrm{vol} / \mathrm{vol}), 3 \% \mathrm{DMSO}$ (vol/vol), and gene-specific primers to maximize detection of rare message with high specificity.

Identification of active $G$ proteins. Activated $\mathrm{G}$ proteins were identified using $\mathrm{P}^{3}$-(4-azidoanilido)- $\mathrm{P}^{1}$-guanosine $5^{\prime}$-triphosphate (AAGTP) as previously described (30). Wild-type NCM460 and NCM460-HIGH cells were grown to near confluence in F-175 flasks, washed in binding buffer, and then mechanically disaggregated using a rubber policeman. Cells were pelleted by centrifugation, resuspended in binding buffer, and kept on ice for $1 \mathrm{~h}$. Cells were repelleted by centrifugation, and then resuspended in ice-cold AAGTP buffer $(10 \mathrm{mM}$ Hepes [pH 7.2], $1 \mathrm{mM} \mathrm{MgCl}$, 3 mM PMSF, $1 \mathrm{mM}$ 2-mercaptoethanol, and $5 \mu \mathrm{g} / \mathrm{ml}$ leupeptin). Cells were punctured using a sonicator, an aliquot removed for protein determination, and $70 \mu \mathrm{g}$ cells aliquoted per reaction into tubes containing $20 \mu \mathrm{M}$ GDP, $0.1 \mu \mathrm{M}$ ${ }^{32} \mathrm{P}$-AAGTP, and the indicated peptide. The cell mixture was removed from ice, rapidly warmed to $22^{\circ} \mathrm{C}$ for $10 \mathrm{~min}$, and the reaction halted with $5 \mathrm{mM}$ DTT. Cross-linking of activated G protein(s) to ${ }^{32} \mathrm{P}-\mathrm{AAGTP}$ was achieved by placing the reaction tubes in a Stratalinker (Stratagene, Inc.) and exposing to $150 \mathrm{~mJ}$ UV energy. To each tube, $2 \mu \mathrm{l}$ DNase I was added for $2 \mathrm{~min}$ at $37^{\circ} \mathrm{C}$ to decrease sample viscosity. The samples were warmed to $70^{\circ} \mathrm{C}$ for $4 \mathrm{~min}$ and resolved by SDS-PAGE ( $12 \%$ acrylamide gel). The radioactive bands on dried gels were identified using a PhosphoImager (Molecular Dynamics, Sunnyvale, CA).

Measurement of phosphoinositides. Total cellular phosphoinositides were determined as described previously $(31,32)$. Briefly, disaggregated cells at a concentration of 500,000/well in colonocyte media containing $100 \mu \mathrm{Ci} / \mathrm{ml}$ myo-2- $\left[{ }^{3} \mathrm{H}\right]$ inositol and $2 \%$ fetal bovine serum were plated in 24-well tissue culture trays. At this plating density cells were equally confluent $24 \mathrm{~h}$ later. Cells were then washed and incubated in binding buffer additionally containing $10 \mathrm{mM} \mathrm{LiCl}_{2}$ for 15 min, and then for $60 \mathrm{~min}$ at $37^{\circ} \mathrm{C}$ with agonists at various concentrations. Reactions were halted by adding $1 \% \mathrm{HCl}$ in methanol, and total $\left[{ }^{3} \mathrm{H}\right]$ inositol phosphates isolated by anion exchange chromatography. After loading the anion exchange column, free $\left[{ }^{3} \mathrm{H}\right]$ inositol was removed by washing with water, $\left[{ }^{3} \mathrm{H}\right]$ glycerophosphoryl inositol was removed by washing with $5 \mathrm{mM}$ sodium tetraborate in $60 \mathrm{mM}$ sodium formate, and total $\left[{ }^{3} \mathrm{H}\right]$ inositol phosphates were eluted with $100 \mathrm{mM}$ 
formic acid in $1 \mathrm{M}$ ammonium formate. Elutes were assayed in a TriCarb 1600TR Packard Scintillation Counter (Meridian, CT) after the addition of hydro-fluor scintillation fluid (32).

\section{Results}

Determination of receptor binding. As previously demonstrated (11), both NCM460-HIGH and NCM460-LOW expressed GRP-R that bound agonist and antagonist similarly to that which has been described for the natively expressed human receptor. Specifically, NCM460-HIGH cells $(\sim 5,000$ binding sites/cell $)$ bound GRP with high affinity $\left(K_{\mathrm{i}}=0.7 \pm 0.1 \mathrm{nM}\right)$ but not the bombesin-related peptide neuromedin B $\left(K_{\mathrm{i}}=244 \pm 27\right.$ $\mathrm{nM}$ ) (Fig. 1). In contradistinction, the antagonists [D-Phe ${ }^{6}$ $\left.\operatorname{Leu}^{13}(\psi 13-14) \mathrm{CPA}^{14}\right]$ bombesin $(6-14)\left(K_{\mathrm{i}}=0.8 \pm 0.2 \mathrm{nM}\right)$ and D-Phe ${ }^{6}$-bombesin methyl ester $\left(K_{\mathrm{i}}=0.9 \pm 0.1 \mathrm{nM}\right)$ bound to the transfected receptor with affinity equal to that observed for GRP (Fig. 1). Likewise NCM460-LOW cells $(\sim 2,100$ binding sites/cell) bound the agonist GRP and the antagonist D-Phe ${ }^{6}$ bombesin methyl ester with equal high affinity as NCM460HIGH cells (11). In contrast, no detectable binding of [ $\left.{ }^{125} \mathrm{I}_{-} \mathrm{Tyr}^{4}\right]$ bombesin was observed to untransfected wild-type NCM460 cells or cells transfected with the empty vector pcDNA-3 (NCM460-VECTOR) (data not shown).

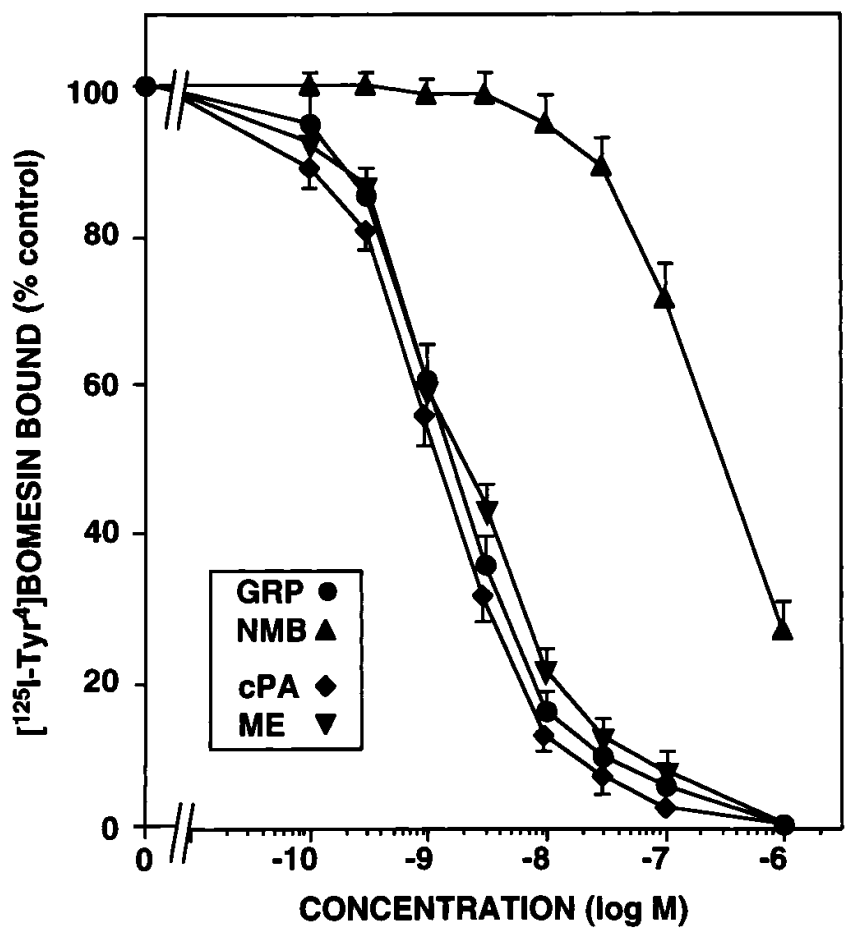

Figure 1. Ability of selected bombesin receptor agonists and antagonists to displace $\left[{ }^{125} \mathrm{I}_{-} \mathrm{Tyr}^{4}\right]$ bombesin binding to GRP-R expressed by NCM460-HIGH cells. In all instances $1.5 \times 10^{6} / \mathrm{ml} \mathrm{NCM460-HIGH} \mathrm{cells}$ were incubated with $50 \mathrm{pM}\left[{ }^{125} \mathrm{I}_{-} \mathrm{Tyr}^{4}\right]$ bombesin for $30 \mathrm{~min}$ at $22^{\circ} \mathrm{C}$ with the indicated concentrations of the agonists gastrin-releasing peptide $(\bullet, G R P)$ and neuromedin $\mathrm{B}(\boldsymbol{\Lambda}, N M B)$, or the antagonists D-Phe ${ }^{6}$-bombesin methyl ester $(\boldsymbol{\nabla}, M E)$ or $\left[\mathrm{D}-\mathrm{Phe}^{6} \mathrm{Leu}^{13}(\psi 13-\right.$ 14) $\left.\mathrm{CPA}^{14}\right]$ bombesin $(6-14)(\bullet, c P A)$. Results are expressed as the mean $\pm \mathrm{SE}$ of at least three separate experiments of the saturably bound radioactivity in the absence of non-radioactive peptide; for each experiment the values were determined in duplicate.

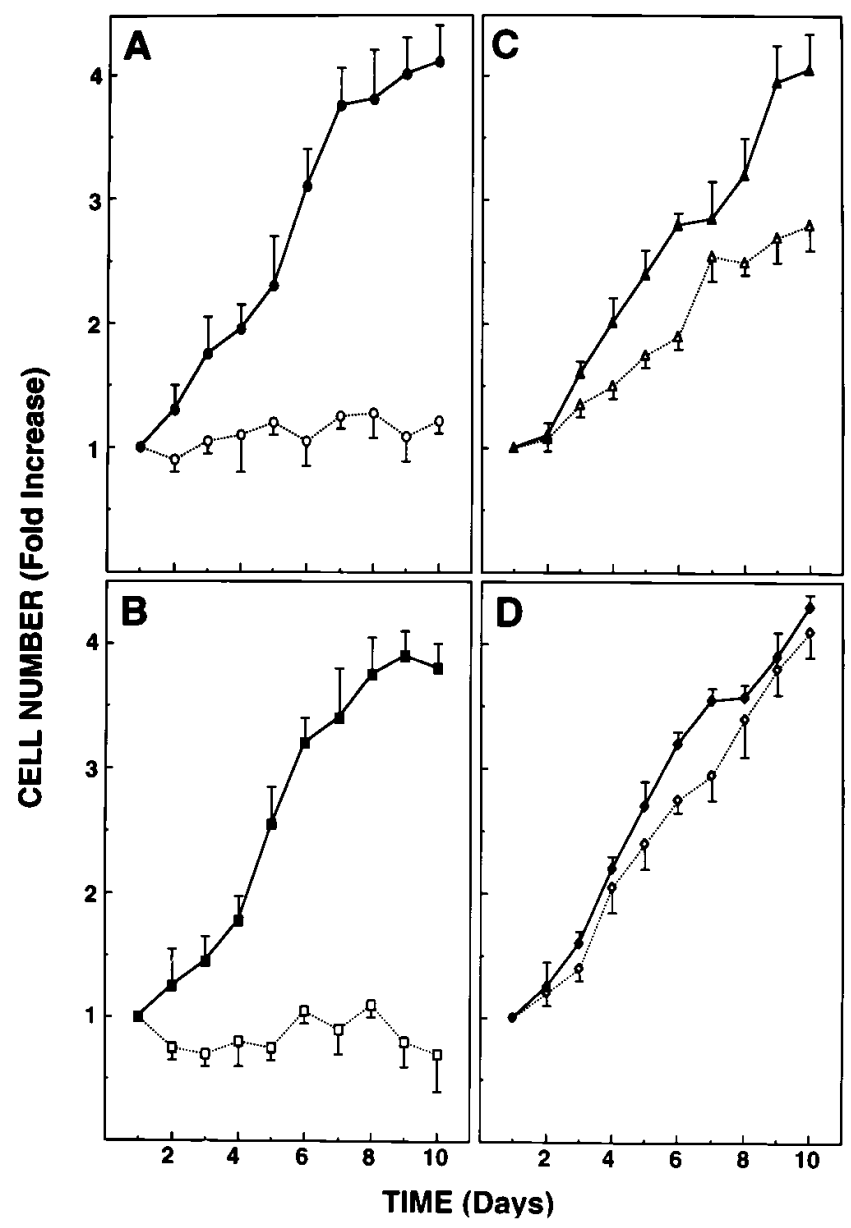

Figure 2. Proliferation rates of wild-type $\operatorname{NCM} 460(\bullet, A)$, NCM460VECTOR $(\boldsymbol{\square}, B)$, NCM460-LOW $(\boldsymbol{\Delta}, C)$, and NCM460-HIGH $(\bullet, D)$ cells. In all instances 50,000 cells were plated in 24-well plates and then cultured in Ham's F-12 medium alone (open symbols) or in complex media (closed symbols) (25) as described in Methods. At the indicated time points, cells were isolated by exposing to $1 \mathrm{mM}$ EDTA in $1 \%$ trypsin, and the viable cells identified by their ability to exclude trypan blue. Results are expressed as the mean \pm SE of at least five separate paired experiments.

Effect of GRP-R expression on NCM460 cell proliferation. Given the ability of the GRP-R to cause the proliferation of human stomach (33-35) and colon cancer (14-17) cell lines, we next determined whether ectopic receptor expression altered the growth characteristics of transfected NCM460 cells. Nontransfected NCM460 cells were similar to rabbit colonocytes maintained in primary culture insofar as they required a complex defined media for survival (25). When cultured in Ham's F-12 supplemented with $0.5 \mathrm{U} / \mathrm{ml}$ insulin, $0.4 \mu \mathrm{g} / \mathrm{ml}$ hydrocortisone, $0.58 \mu \mathrm{g} / \mathrm{ml}$ glutamine, and $20 \%$ fetal bovine serum, NCM460 cells doubled every $\sim 4 \mathrm{~d}$ (Fig. $2 A$ ). Yet when nontransfected NCM460 were cultured in Ham's F-12 media alone, the cells did not proliferate (Fig. $2 A$ ); and after $7 \mathrm{~d}$ in this environment the cells appeared pynknotic and were dying (Fig. 3). Similar to wild-type NCM460 cells, NCM460-VECTOR cells also exhibited serum- and growth factor-dependent growth (Fig. 2 B). Expression of GRP-R, however, allowed for transfected NCM460 cells to proliferate independently of serum and 

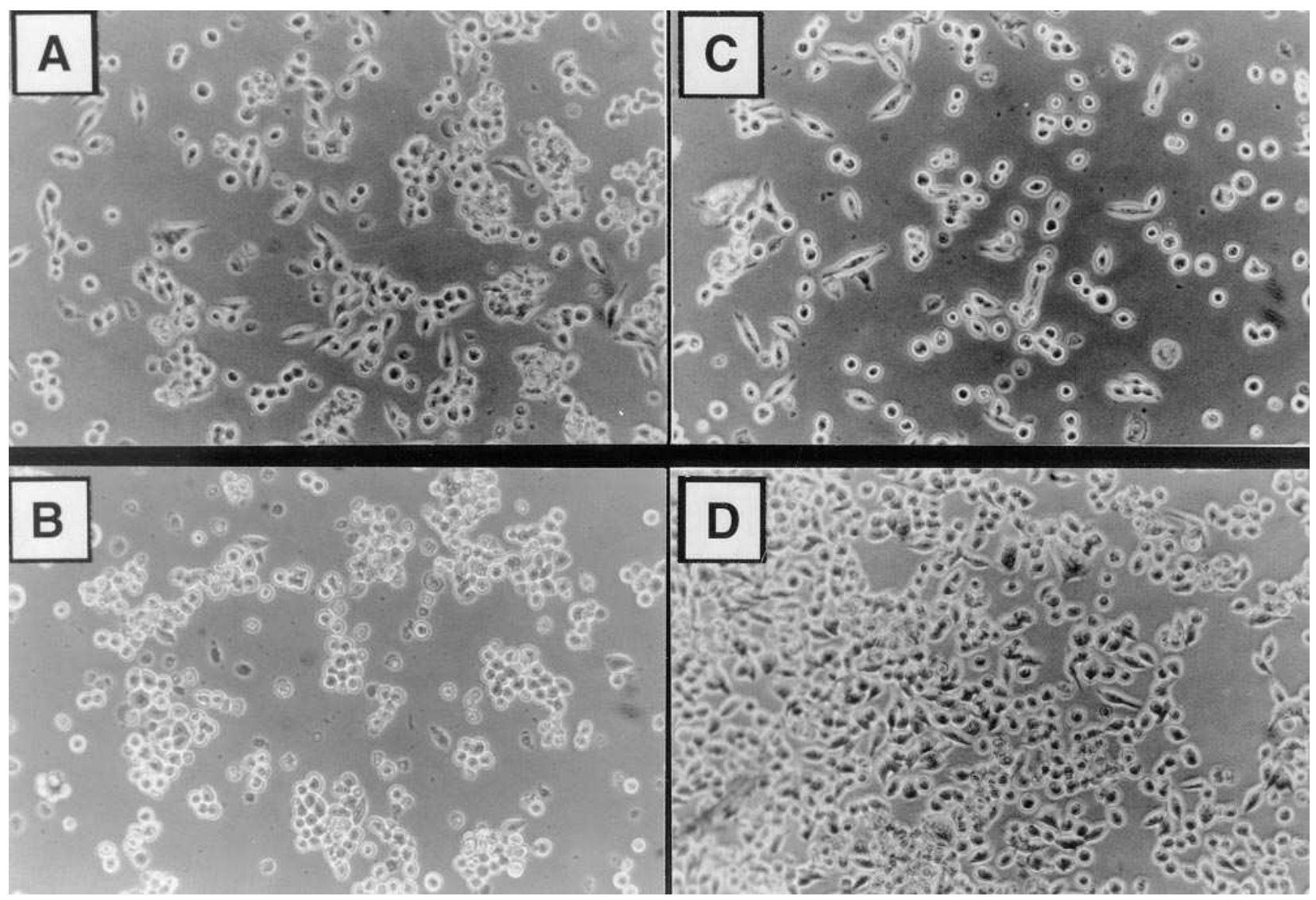

Figure 3. Morphology of NCM460 ( $A$ and $B)$ and NCM460-HIGH ( $C$ and $D)$ cells in simple media. In all instances 50,000 cells were plated in 24well plates and cultured in Ham's F-12 alone. After $1(A$ and $C)$ and $7(B$ and $D)$ d in culture, photographs were taken at a magnification of 250 using Kodak Tri-Pan film (ASA 100). Photographs are representative of at least three separate observations.

growth factors, and in a receptor concentration-dependent fashion (Fig. 2, $C$ and $D$ ). After $10 \mathrm{~d}$ in Ham's F-12 alone, NCM460-LOW cells achieved $\sim 70 \%$, and NCM460-HIGH cells $\sim 95 \%$, of the proliferative capacity of either cell type grown in the presence of serum and growth factors (Fig. 2). Indeed, the proliferation rate of NCM460-HIGH cells was similar whether cultured in complex or simple media (Fig. $2 \mathrm{D}$ ); with these cells appearing healthy and able to progress to a confluent monolayer, even in the absence of serum or growth factors (Fig. 3). These results demonstrate that GRP-R-expressing NCM460 cells are able to proliferate independently of serum and growth factors.

NCM460 cells do not synthesize GRP. Two potential mechanisms could account for the ability of NCM460 cells expressing GRP-R, but not wild-type NCM460 cells, to proliferate independently of serum and growth factors. Either transfected cells secrete GRP, thus allowing this peptide to act as an autocrine growth factor, or the GRP-R itself is active independent of ligand stimulation, i.e., is constitutively activated. To determine whether NCM460 or NCM460-HIGH cells could secrete GRP, we performed RT-PCR to detect message for this peptide. When PCR was performed as described in Methods, GRP message could not be detected in either cell type (Fig. 4). As a positive control, message was detected in NCI-H128 cells, a human small cell lung cancer cell line previously shown to secrete GRP (Fig. 4) (21).
Effect of agonists and antagonists on cell proliferation. We next determined the effect of various antagonists on cell proliferation (Fig. 5), as determined by measuring changes in cellular $\left[{ }^{3} \mathrm{H}\right]$ thymidine incorporation. After $7 \mathrm{~d}$ in Ham's F-12 alone, NCM460 cells not expressing GRP-R were growth arrested (Fig. 2), dying (Fig. 3), and incorporated relatively little $\left.{ }^{\beta} \mathrm{H}\right]$ thymidine (Fig. 5, $A$ and $B$ ). In contrast, NCM460 cells treated

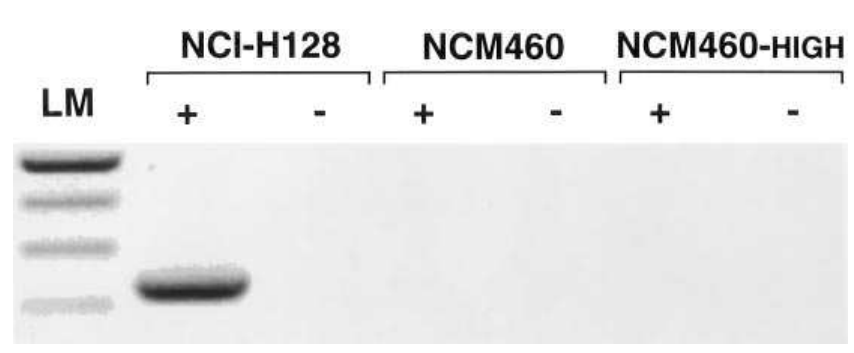

Figure 4. Identification of GRP message in NCI-H128 cells, NCM460 cells, NCM460-HIGH cells by reverse transcriptase-PCR (RT-PCR). RNA was obtained using the method of Chomczynski and Sacchi (29), followed by RT-PCR as described in Methods. Presence or absence of RT in the indicated lanes is indicated by $\pm ; \mathrm{LM}=100$-bp marker (Gibco/BRL), with the top band representing the 500-bp marker. NCI-H128 cells serve as a positive control as they are known to secrete GRP (21). 


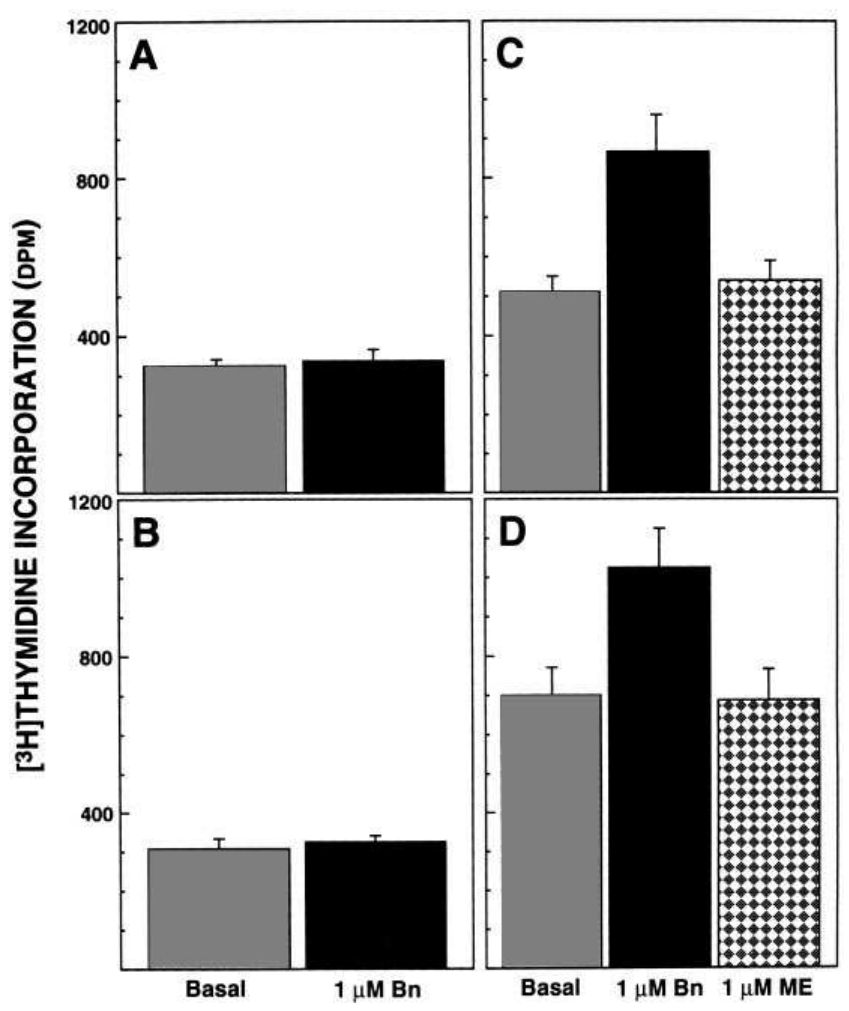

Figure 5. $\left[{ }^{3} \mathrm{H}\right]$ Thymidine incorporation in wild-type NCM460 $(A)$, NCM460-VECTOR $(B)$, NCM460-LOW $(C)$, and NCM460-HIGH $(D)$ cells. In all instances 50,000 cells were plated in 24-well tissue culture plates and cultured in Ham's F-12 alone for $7 \mathrm{~d}$. During the final $8 \mathrm{~h}$ of incubation $1 \mu \mathrm{Ci} / \mathrm{ml}$ of $\left[{ }^{3} \mathrm{H}\right]$ thymidine alone or with the indicated peptide was added. Data are expressed as the mean \pm SE of at least three separate experiments.

identically for the same period of time but expressing GRP-R proliferated actively (Fig. 2), appeared morphologically healthy (Fig. 3), and incorporated $\left[{ }^{3} \mathrm{H}\right]$ thymidine in a receptor concentration-dependent fashion (Fig. 5, $C$ and $D$ ). Specifically, basal $\left[{ }^{3} \mathrm{H}\right]$ thymidine uptake levels were $>70 \%$ higher in NCM460LOW cells $(P<0.05$, one-way ANOVA $)$, and $>90 \%$ higher in NCM460-HIGH cells $(P<0.05$, one-way ANOVA), as compared with that observed for either wild-type NCM460 or NCM460-vECTOR cells (Fig. 5). Exposure to $1 \mu \mathrm{M}$ bombesin for $8 \mathrm{~h}$ increased $\left[{ }^{3} \mathrm{H}\right]$ thymidine uptake by $\sim 50 \%$ in cells expressing GRP-R as compared with control cells processed in parallel, whereas NCM460 and NCM460-VECTOR cells did not respond when treated with agonist (Fig. 5). In contrast, the rates of $\left[{ }^{3} \mathrm{H}\right]$ thymidine incorporation observed in NCM460HIGH and NCM460-LOW cells consequent to treatment with $1 \mu \mathrm{M}$ D-Phe ${ }^{6}$-bombesin methyl ester was similar to that observed in untreated cells (Fig. 5). Thus these data indicate that whereas the basal proliferation rates of NCM460 cells expressing GRP-R could be increased by exposure to agonist, receptor-specific antagonists had no effect on altering cell growth. This finding is characteristic of constitutively activated receptors.

Activation of G $\alpha$ q/11 in NCM460-HIGH cells. To further investigate the possibility that the GRP-R ectopically expressed by transfected NCM460 cells could be constitutively activated, we directly measured the $G$ proteins activated using the nonhydrolyzable GTP photoaffinity analog azidoanilido GTP (AAGTP). NCM460 and NCM460-HIGH cells were grown to confluence, mechanically disaggregated, permeabilized by sonication, and then resuspended at a concentration of $10 \mu \mathrm{g} / \mu \mathrm{l}$. Permeabilized cells were incubated on ice with $20 \mu \mathrm{M}$ GDP, $500 \mu \mathrm{M}$ ATP, $0.1 \mu \mathrm{M}\left[{ }^{32} \mathrm{P}\right] \mathrm{AAGTP}$, and with or without $1 \mu \mathrm{M}$ bombesin. The reaction tubes were then rapidly warmed to $37^{\circ} \mathrm{C}$ for $10 \mathrm{~min}$, the reaction stopped by adding DTT, and the product resolved on a $12 \%$ SDS polyacrylamide gel. In unstimulated wild-type NCM460 cells, [ $\left[{ }^{32} \mathrm{P}\right]$ AAGTP did not bind to any other detectable protein (Fig. 6). Stimulation with $1 \mu \mathrm{M}$ bradykinin, and which acts to activate phospholipase C (36, 37), resulted in a single 41-kD protein being identified (Fig. 6). In contrast, $\left[{ }^{32} \mathrm{P}\right] \mathrm{AAGTP}$ bound to an identically sized protein in unstimulated NCM460-HIGH cells, with $1 \mu \mathrm{M}$ bombesin increasing the amount of $41-\mathrm{kD}$ protein detected by about twofold (Fig. 6). Specifically, volume quantification analysis performed using a PhosphoImager revealed that the $41-\mathrm{kD}$ band for NCM460-HIGH cells increased from $89,100 \pm 4,400$ to $153,700 \pm 7,000$ after stimulation with $1 \mu \mathrm{M}$ bombesin. We then transferred this protein to nitrocellulose and immunoblotted with an antibody to anti-G $\alpha q / 11$ (24), confirming its identity as this particular heterotrimeric $\mathrm{G}$ protein (data not shown).

Constitutive activation of phospholipase $C$. To investigate the functional significance of basal G $\alpha \mathrm{q} / 11$ activation, we next determined the degree of cellular phospholipase $\mathrm{C}$ activation. In quiescent wild-type NCM460 cells, basal activation of phospholipase $C$ was low $(493 \pm 26 \mathrm{dpm})$ and was not affected by exposing to $1 \mu \mathrm{M}$ bombesin ( $485 \pm 18 \mathrm{dpm}$ ) (Fig. 7). Stimula-

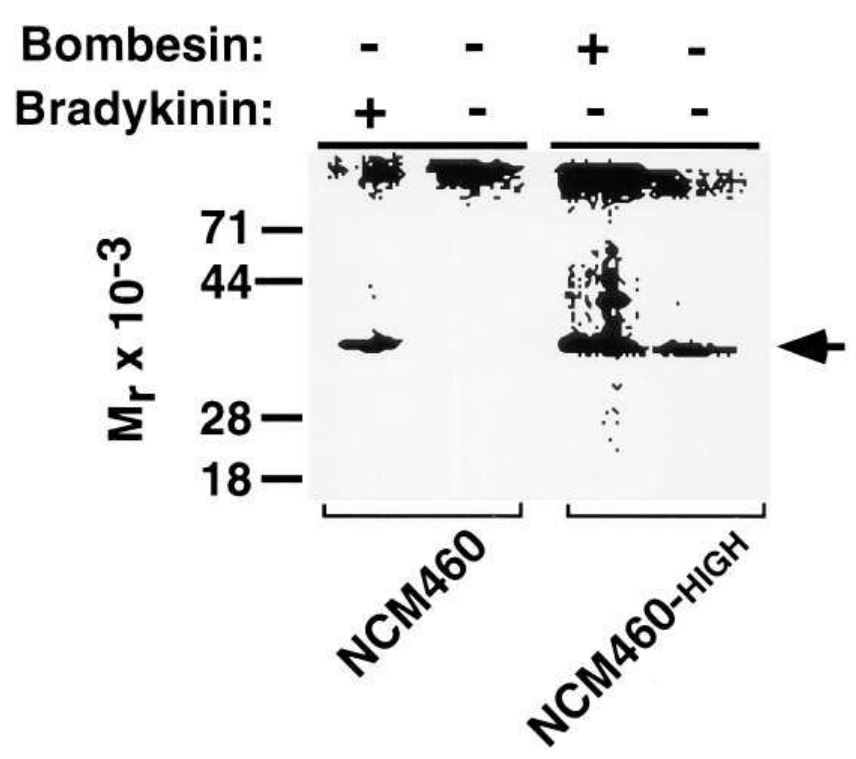

Figure 6. Identification of activated $\mathrm{G}$ proteins in NCM460 and NCM460-HIGH cells using $\left[\mathrm{P}^{3}\right.$-(4-azidoanilido)- $\mathrm{P}^{1}$-guanosine $5^{\prime}$-triphosphate] (AAGTP). As described in Methods, $70 \mu \mathrm{g}$ of native or transfected NCM460 cells underwent sonication and were then loaded with $0.1 \mu \mathrm{M}{ }^{32} \mathrm{P}$-AAGTP. Cells were exposed to the indicated peptide for $10 \mathrm{~min}$ at $22^{\circ} \mathrm{C}$, the reaction halted with $5 \mathrm{mM}$ DTT, the activated $\mathrm{G}$ proteins crosslinked to ${ }^{32} \mathrm{P}$-AAGTP, and the products resolved by SDS-PAGE ( $12 \%$ gel). The radioactive products were detected using a PhosphoImager. This gel is representative of at least three separate experiments. 


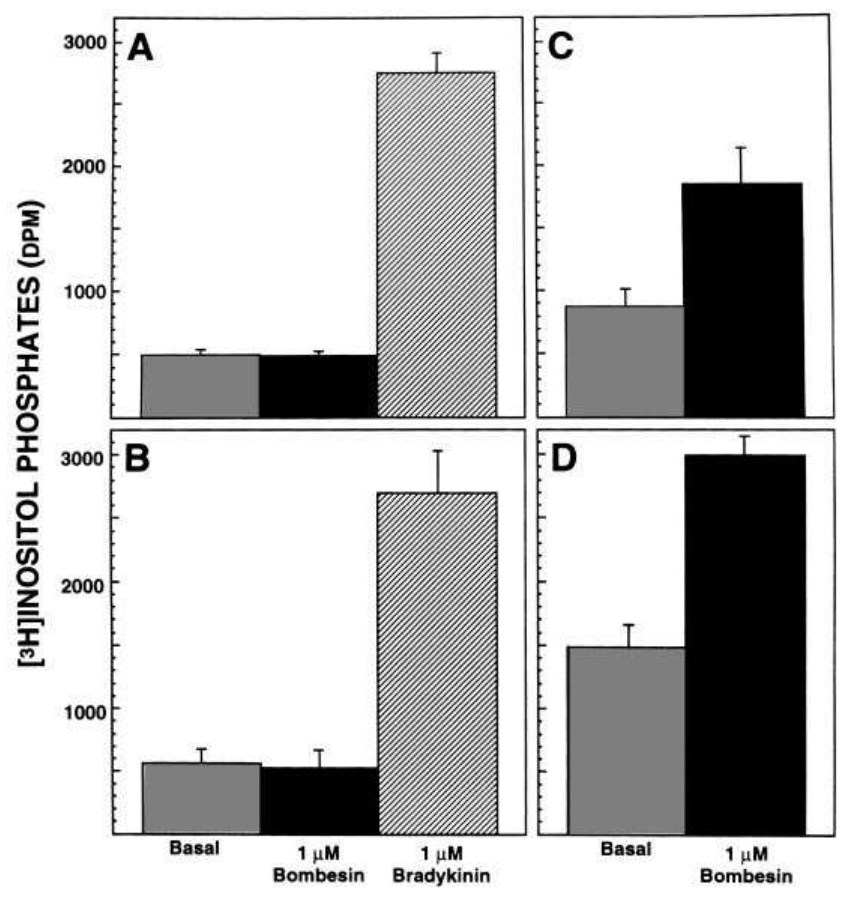

Figure 7. Ability wild-type NCM460 (A), NCM460-VECTOR $(B)$, NCM460-LOW $(C)$, and NCM460-HIGH $(D)$ cells to increase cellular $\left[{ }^{3} \mathrm{H}\right]$ inositol phosphates. In all instances 500,000 cells were placed in 24-well tissue culture plates for $24 \mathrm{~h}$ containing $100 \mu \mathrm{Ci} / \mathrm{ml}$ myo$2-\left[{ }^{3} \mathrm{H}\right]$ inositol in colonocyte media containing $2 \%$ FBS. Cells were washed, exposed to the indicated peptide for $60 \mathrm{~min}$ at $37^{\circ} \mathrm{C}$, and $\left[{ }^{3} \mathrm{H}\right]$ inositol phosphates isolated as described in Methods. Data are expressed as the mean $\pm \mathrm{SE}$ of at least three separate experiments.

tion with $1 \mu \mathrm{M}$ bradykinin increased $\left[{ }^{3} \mathrm{H}\right]$ inositol phosphate turnover by more than fivefold (Fig. 7), reflecting maximal phospholipase C activity in NCM460 cells. NCM460-VECTOR cells behaved similarly, possessing low basal levels of $\left[{ }^{3} \mathrm{H}\right]$ inositol phosphates, lacking responsiveness to $1 \mu \mathrm{M}$ bombesin, and likewise increasing these levels in response to $1 \mu \mathrm{M}$ bradykinin (Fig. 7). Thus transfection with the expression vector pcDNA-3 alone did not alter NCM460 cellular behavior. In contrast, NCM460-LOW cells had increased $\left[{ }^{3} \mathrm{H}\right]$ inositol phosphate levels in the absence of stimulation with agonist $(857 \pm 41)$; with this level increasing approximately twofold when stimulated with $1 \mu \mathrm{M}$ bombesin $(1,825 \pm 212)$. With the increased expression of GRP-R observed in NCM460-HIGH cells, basal $\left[{ }^{3} \mathrm{H}\right]$ inositol phosphate levels were also increased $(1,437 \pm 122)$. Maximal $\left[{ }^{3} \mathrm{H}\right]$ inositol phosphate levels in NCM460HIGH cells consequent to stimulation with $1 \mu \mathrm{M}$ bombesin likewise were increased $(3,011 \pm 149)$ as compared with NCM460LOW cells. Thus these data indicate that ectopic GRP-R expression by the nonmalignant human colon epithelial cell line NCM460 is sufficient to render the receptor constitutively active, with the degree of phospholipase $\mathrm{C}$ activation roughly proportional to the receptor number.

Effect of galanin-1 receptor expression in NCM460 cells. Finally, to confirm the specificity of GRP-R constitutive activation, we studied NCM460-GAL cells. Binding studies revealed that NCM460-GAL cells have high affinity for galanin $\left(K_{\mathrm{i}}=1.4 \pm 0.3 \mathrm{nM}\right)$, while Scatchard analysis of the binding data showed that there were a similar number of galanin bind- ing sites as there were GRP-R binding sites in NCM460-HIGH cells (data not shown). Basal levels of $\left[{ }^{3} \mathrm{H}\right]$ thymidine incorporation $(261 \pm 20)$ and $\left[{ }^{3} \mathrm{H}\right]$ inositol phosphate turnover $(598 \pm$ 11) in NCM460-GAL cells were low (Fig. 8) and similar to that observed in wild-type NCM460 and NCM460-VECTOR cells. Stimulation with $1 \mu \mathrm{M}$ bombesin failed to significantly alter either parameter (Fig. 8). Thus these data indicate that the GRP-R constitutive activation observed in NCM460 cells is receptor specific.

\section{Discussion}

In this study we demonstrate that GRP-R expression by a nonmalignant human colon epithelial cell line is sufficient to render it constitutively active, and allows serum- and growth factor-independent cell growth. This observation is important because epithelial cells lining the human colon do not normally express GRP-R (11), whereas this receptor is expressed by $>30 \%$ of colon cancer cell lines (16) and $40 \%$ of resected colon cancers (13). In spite of the fact that agonist can cause the proliferation of many cells expressing GRP-R, GRP and related agonists are not known to be present in the intestinal lumen or in the lamina propria surrounding normal colonocytes; thus the mechanism whereby this receptor can cause the proliferation of colon cancers remains to be established. Our finding that ectopic GRP-R expression by NCM460 cells is sufficient to render it constitutively active potentially provides a clinically relevant mechanism whereby this receptor can cause cell growth independent of agonist stimulation.

We herein demonstrate that the human GRP-R ectopically expressed by NCM460 cells binds agonist and antagonist similarly to that which has been described in other cells (11). Yet unlike what is observed in other cells, GRP-R expressed by NCM460 cells are basally coupled to and cause the activation of $\mathrm{G} \alpha \mathrm{q} / 11$. As a consequence of this GRP-R-G $\alpha \mathrm{q} / 11$ interaction, NCM460 cells are altered such that they are now capable of proliferating independently of agonist, serum, or other growth factors otherwise essential for the culture of nontransfected NCM460 cells. Since the GRP-R does not cause the proliferation of all cells in which it is expressed (27), our data suggest
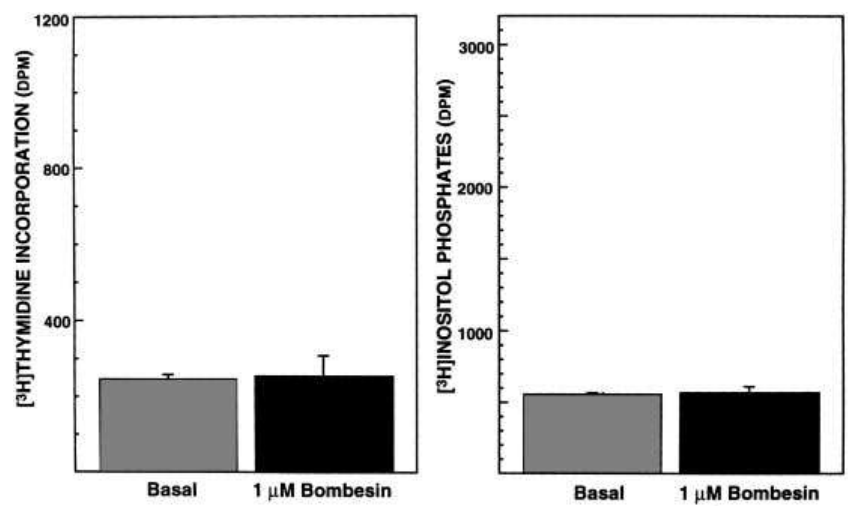

Figure 8. Ability of NCM460-GAL cells to increase cellular $\left[{ }^{3} \mathrm{H}\right]$ thymidine (left) or and $\left[{ }^{3} \mathrm{H}\right]$ inositol phosphates (right). Cells were cultured and assayed for $\left[{ }^{3} \mathrm{H}\right]$ thymidine incorporation and $\left[{ }^{3} \mathrm{H}\right]$ inositol phosphate turnover as described in Methods either alone or after exposure to $1 \mu \mathrm{M}$ bombesin. Data are expressed as the mean $\pm \mathrm{SE}$ of at least three separate experiments. 
that certain tissues such as human colon epithelial cells may be better able to provide the milieu necessary for this receptor to act as an oncogene.

NCM460 cells are the only nonmalignant human colon epithelial cell line available, and as such provide a unique opportunity for evaluating the functional consequence of GRP-R expression by colonocytes. NCM460 cells were originally derived from the transverse colon (23). Ongoing studies demonstrate that these cells possess many features characteristic of enterocytes derived from this location including their expression of NHE-1 and -3 antiports, ability to form tight junctions, and engage in vectorial $\mathrm{Cl}^{-}$transport $(38,39)$. Yet NCM460 cells do not form tumors in nude mice and are not clonogenic in soft agar (23), features consistent with a nonmalignant phenotype. Thus it appears unlikely that the constitutive activation of the GRP-R described herein reflects clonal expansion of a single abnormal cell type; indeed, we observed GRP-R constitutive activation in two different stably transfected cell lines.

Constitutive activation of seven transmembrane-spanning, $\mathrm{G}$ protein-coupled (heptaspanning) receptors is a phenomenon that only recently has been described, and generally is associated with the presence of autoactivating receptor mutations. For example, clinical conditions as diverse as thyroid adenomas and familial precocious puberty are due to constitutively activating mutations in the TSH $(40,41)$ and $\mathrm{LH}(42,43)$ receptors, respectively. In contrast, only two reports exist describing constitutive activation independent of heptaspanning receptor mutation. In one, autoactivation of the $\mu$-opioid receptor was observed in patients consequent to prolonged exposure to agonist; the investigators proposed that constitutive activation of this receptor by pharmacological manipulation may account for the clinical phenomenon of narcotic tolerance (44). In the other, the dopamine D1B but not the D1A receptor was found to have high agonist-independent activity (45). In neither case, however, was receptor autoactivation shown to be tissue specific or to functionally result in cell proliferation. In contrast, we demonstrate constitutive activation of the human GRP-R consequent to its expression in NCM460 cells, a phenomenon that has not been described in other cell lines in which it has been expressed.

There are some observations pertinent to the GRP-R that may at least partially explain why this receptor may be more susceptible to constitutive activation than other heptaspanning receptors. Our previous (31) and ongoing (46) studies demonstrate that all GRP-R mutations acting to uncouple this receptor from its cognate $\mathrm{G}$ protein(s) also act to decrease receptor affinity for ligand. In contradistinction, we herein demonstrate increased receptor affinity for agonist by the constitutively activated GRP-R. This finding suggests that the GRP-R is potentially in association with its cognate G proteins in its "resting" or basal state. Recent work by Lefkowitz et al. (47) support this suggestion by indicating that heptaspanning receptors and their cognate $\mathrm{G}$ proteins are in a state of dynamic equilibrium, with ligand acting to stabilize the receptor-G protein complex. However, the GRP-R may differ from other heptaspanning receptors by virtue of the fact that at least in NCM460 cells this receptor does not require the stabilizing effects of ligand.

This study also sheds light on what may be an essential component to GRP-R-induced cell proliferation. Previous studies investigating the ability of this receptor to increase cellular cAMP levels by comparing Balb 3T3 and Swiss 3T3 cells (27), or by directly inhibiting cellular cAMP accumulation (48), have suggested that this second messenger is critical for the GRP-R's growth promoting effects. In contrast, others have suggested that small GTP-binding proteins of the $\mathrm{p} 21^{\mathrm{RAS}}$ family are of central importance $(49,50)$. We have previously shown that CAMP is not increased in transfected NCM460expressing GRP-R consequent to agonist stimulation (11); while there is no evidence using azidoanilido GTP crosslinking that any $\mathrm{G}$ protein other than $\mathrm{G} \alpha \mathrm{q} / 11$ is activated by the GRP-R. Finally, the GRP-R is well known to be activated in an autocrine fashion in at least small cell lung cancer. Yet we were unable to detect GRP expression by NCM460 cells; nor could we alter $\left[{ }^{3} \mathrm{H}\right]$ thymidine uptake in GRP-R-expressing NCM460 cells using various bombesin receptor antagonists, a feature characteristic of constitutively activated heptaspanning receptors. Indeed, attenuation of constitutively active receptors requires use of an inverse agonist; and such a compound has yet to be identified for the GRP-R. Thus in at least a human colon epithelial cell line, GRP-R-induced cell proliferation occurs via $\mathrm{G} \alpha \mathrm{q} / 11$ activating phospholipase $\mathrm{C}$. In this regard, the recently described interactions between $\mathrm{G} \alpha \mathrm{q} / 11$, phospholipase $\mathrm{C}$, and the cellular cytoskeleton may hold clues to the proliferative effects described here (51).

In conclusion, we herein demonstrate that the GPR-R ectopically expressed by the nonmalignant human colon epithelial cell line NCM460 is constitutively active and acts to cause cell proliferation. This study provides the first evidence of heptaspanning receptor constitutive activation independent of mutation or pharmacological manipulation, and suggests a role for the GRP-R as an oncogene in colon cancer.

\section{Acknowledgments}

We would like to thank Drs. J.F. Battey, R.T. Jensen, D.R. Manning, and M.P. Moyer for providing materials essential to the completion of this project.

This work was funded by an American Digestive Health Foundation/American Gastroenterological Association Industry Research Scholar Award and by a Schweppe Foundation Award (to R.V. Benya); as well as by a National Institutes of Health grant MH39595 (to M.M. Rasenick).

\section{References}

1. Battey, J.F., J.M. Way, M.H. Corjay, H. Shapira, K. Kusano, R. Harkins, J.M. Wu, T. Slattery, E. Mann, and R.I. Feldman. 1991. Molecular cloning of the bombesin/gastrin-releasing peptide receptor from Swiss 3 T3 cells. Proc. Natl. Acad. Sci. USA. 88:395-399.

2. Spindel, E.R., E. Giladi, P. Brehm, R.H. Goodman, and T.P. Segerson. 1990. Cloning and functional characterization of a complimentary DNA encoding the murine fibroblast bomesin/gastrin-releasing peptide receptor. $\mathrm{Mol}$. Endocrinol. 4:1956-1963.

3. Corgay, M.H., D.J. Dobrzanski, J.M. Way, J. Viallet, H. Shapira, P. Worland, E.A. Sausville, and J.F. Battey. 1991. Two distinct bombesin receptor subtypes are expressed and functional in human lung carcinoma cells. J. Biol. Chem. 266:18771-18779.

4. Severi, C.R., R.T. Jensen, V. Erspamer, L. D'Arpino, D.H. Coy, A. Torsoli, and G. Delle Fave. 1991. Different receptors mediate the action of bombesin-related peptides on gastric smooth muscle cells. Am. J. Physiol. 260:G683G690.

5. Moghimzadeh, E., R. Ekman, R. Hakanson, N. Yanaihara, and F. Sundler. 1983. Neuronal gastrin-releasing peptide in the mammalian gut and pancreas. Neurosciences. 10:541-548.

6. Narayan, S., E. Draviam, S. Rajaraman, and P. Singh. 1991. High-affinity binding sites for bombesin on mouse colonic mucosal membranes. Mol. Cell. Biochem. 106:31-39.

7. Traynor, T.R., and S.M. O'Grady. 1996. Regulation of colonic ion transport by GRP. I. GRP stimulates transepithelial K and Na secretion. Am. J. Physiol. 270:C848-C858.

8. Seybold, V.S., A.M. Parsons, L.M. Aanonsen, and D.R. Brown. 1990. 
Characterization and autoradiographic localization of gastrin releasing peptide receptors in the porcine gut. Peptides (Tarryt.). 11:779-787.

9. Chang, E.B., D.R. Brown, N.S. Wang, and M. Field. 1986. Secretagogueinduced changes in membrane calcium permeability in chicken and chinchilla ileal mucosa. J. Clin. Invest. 78:281-287.

10. Kachur, J.F., R.J. Miller, M. Field, and J. Rivier. 1982. Neurohumoral control of ileal electrolyte transport. I. Bombesin and related peptides. J. Pharmacol. Exp. Ther. 220:449-455.

11. Ferris, H.A., R.E. Carroll, D.L. Lorimer, and R.V. Benya. 1997. Location and characterization of the human GRP receptor expressed by gastrointestinal epithelial cells. Peptides (Tarryt.). 18:663-672.

12. Preston, S.R., L.F. Woodhouse, S. Jones-Blackett, G.V. Miller, and J.N. Primrose. 1995. High-affinity binding sites for gastrin-releasing peptide on human colorectal cancer tissue but not uninvolved mucosa. Br. J. Cancer. 71:10871089.

13. Radulovic, S.S., S.R. Milovanovic, S.Z. Cai, and A.V. Schally. 1992. The binding of bombesin and somatostatin and their analogues to human colon cancers. Proc. Soc. Exp. Biol. Med. 200:394-401.

14. Radulovic, S., G. Miller, and A.V. Schally. 1991. Inhibition of growth of HT-29 human colon cancer xenografts in nude mice by treatment with bombesin/gastrin releasing peptide antagonist (RC-3095). Cancer. Res. 51:6006-6009.

15. Frucht, H., A. Gazdar, and R.T. Jensen. 1991. Human colon cancer cell line NCI-H716 expresses functional bombesin receptors. Proc. Am. Assoc. Cancer Res. 32:47-52.

16. Frucht, H., A.F. Gazdar, J.A. Park, H. Oie, and R.T. Jensen. 1992. Characterization of functional receptors for gastrointestinal hormones on human colon cancer cells. Cancer Res. 52:1114-1122.

17. Radulovic, S., A.V. Schally, H. Reile, G. Halmos, K. Szepeshazi, K. Groot, S. Milovanovic, G. Miller, and T. Yano. 1994. Inhibitory effects of antagonists of bombesin/gastrin releasing peptide (GRP) and somatostatin analog (RC-160) on growth of HT-29 human colon cancers in nude mice. Acta Oncol. 33:693-701.

18. Giacchetti, S., C. Gauville, P. De Cremoux, L. Bertin, P. Berthon, J.-P. Abita, F. Cuttitta, and F. Calvo. 1990. Characterization, in some human breast cancer cell lines, of gastrin-releasing peptide-like receptors which are absent in normal breast epithelial cells. Int. J. Cancer. 46:293-298.

19. Reile, H., P.E. Armatis, and A.V. Schally. 1994. Characterization of high-affinity receptors for bombesin/gastrin-releasing peptide on the human prostate cancer cell lines PC-3 and DU-145: internalization of receptor bound ${ }^{125} \mathrm{I}-\left[\mathrm{Tyr}^{4}\right]$ bombesin by tumor cells. Prostate. 25:29-38.

20. Pinski, J., A.V. Schally, G. Halmos, and K. Szepeshazi. 1993. Effect of somatostatin analog RC-160 and bombesin/gastrin-releasing peptide antagonist RC-3095 on growth of PC-3 human prostate-cancer xenografts in nude mice. Int. J. Cancer. 55:963-967.

21. Cuttitta, F., D.N. Carney, J. Mulshine, T.W. Moody, J. Fedorko, A. Fishler, and J.D. Minna. 1985. Bombesin-like peptides can function as autocrine growth factors in human small-cell lung cancer cells. Nature. 316:823-826.

22. Moody, T.W., D.N. Carney, F. Cuttitta, K. Quattrocchi, and J.D. Minna. 1985. High affinity receptors for bombesin/GRP-like peptides on human small cell lung cancer. Life Sci. 37:105-113.

23. Moyer, M.P., J. Stauffer, L. Manzano, L. Tanzer, and R. Merriman. 1996. NCM460, a normal human colon mucosal epithelial cell line. In Vitro Cell. \& Dev. Biol. Anim. 32:315-317.

24. Lounsbury, K.M., P.J. Casey, L.F. Brass, and D.R. Manning. 1991. Phosphorylation of $\mathrm{Gz}$ in human platelets. Selectivity and site of modification. $J$. Biol. Chem. 266:22051-22056.

25. Benya, R.V., L.N. Schmidt, J. Sahi, T.J. Layden, and M.C. Rao. 1991. Isolation, characterization and attachment of rabbit distal colon epithelial cells. Gastroenterology. 101:692-702.

26. Lorimer, D.L., and R.V. Benya. 1996. Cloning and quantification of human galanin-1 receptor expression by mucosal cells lining the gastrointestinal tract. Biochem. Biophys. Res. Commun. 222:379-385.

27. Benya, R.V., Z. Fathi, T. Kusui, T. Pradhan, J.F. Battey, and R.T. Jensen. 1994. Gastrin-releasing peptide receptor-induced internalization, downregulation, desensitization and growth: A possible role for cyclic AMP. Mol. Pharmacol. 46:235-245.

28. Rozengurt, E., and J. Sinnett-Smith. 1983. Bombesin stimulation of DNA synthesis and cell division in cultures of Swiss 3 T3 cells. Proc. Natl. Acad. Sci. USA. 80:2936-2940.

29. Chomczynski, P., and N. Sacchi. 1987. Single-step method of RNA isolation by acid guanidinium thiocyanate-phenol-chloroform extraction. Anal. Bio- chem. 162:156.

30. Rasenick, M.M., M. Talluri, and W.J. Dunn. 1994. Photoaffinity guanosine 5 '-triphosphate analogs as a tool for the study of GTP-binding proteins. Methods Enzymol. 237:100-110.

31. Benya, R.V., M. Akeson, J.E. Mrozinski, R.T. Jensen, and J.F. Battey. 1994. Internalization of the gastrin-releasing peptide receptor is mediated by both phospholipase C-dependent and -independent processes. Mol. Pharmacol. 46:495-501.

32. Berridge, M.J., R.M. Dawson, C.P. Downes, J.P. Helsop, and R.F. Irvine. 1983. Changes in the levels of inositol phosphates after agnoist-dependent hydrolysis of membrane phosphoinositides. Biochem. J. 212:473-482.

33. Preston, S.R., and J.N. Primrose. 1993. Gastrin releasing peptide receptor expression on human gastric cancer cell lines. Gut. 34:S15.

34. Halmos, G., J. Pinski, B. Szoke, and A.V. Schally. 1994. Characterization of bombesin/gastrin-releasing peptide receptors in membranes of MKN45 human gastric cancer. Cancer Lett. 85:111-118.

35. Qin, Y., G. Halmos, R.Z. Cai, B. Szoke, T. Ertl, and A.V. Schally. 1994 Bombesin antagonists inhibit in vitro and in vivo growth of human gastric cancer and binding of bombesin to its receptor. J. Cancer Res. Clin. Oncol. 120: 519-528.

36. Marceau, F. 1995. Kinin B1 receptors: a review. Immunopharmacology. 30:1-26

37. Regoli, D., G. Calo, A. Rizzi, G. Bogoni, F. Gobeil, C. Campobasso, G. Mollica, and L. Beani. 1996. Bradykinin receptors and receptor ligands (with special emphasis on vascular receptors). Regul. Pept. 65:83-89.

38. Sahi, J., J.S. Stauffer, T.J. Layden, M.P. Moyer, and M.C. Rao. 1995. $\mathrm{Cl}^{-}$ transport characteristics of an immortalized human epithelial cell line (N3) derived from the normal transverse colon. Gastroenterology. 208:321a. (Abstr.)

39. Sahi, J., L.N. Schmidt, P. Dudeja, K. Ramaswamy, J.S. Stauffer, M.P. Moyer, T.J. Layden, and M.C. Rao. 1996. $\mathrm{Na}^{+} / \mathrm{H}^{+}$exchange activity of an immortalized human epithelial colonic cell line. Gastroenterology. 110:356a. (Abstr.)

40. Paschke, R., M. Tonacchera, J. Van Sande, J. Parma, and G. Vassart. 1994. Identification and functional characterization of two new somatic mutations causing consitutive activation of the thyrotropin receptor in hyperfunctioning autonomous adenomas of the thyroid. J. Clin. Endocrinol. Metab. 79: 1785-1789.

41. Zhang, M.L., H. Sugawa, S. Kosugi, and T. Mori. 1995. Constitutive activation of the thyrotropin receptor by deletion of a portion of the extracellular domain. Biochem. Biophys. Res. Commun. 211:205-210.

42. Shenker, A., L. Laue, S. Kosugi, J.J. Merendino, T. Minegishi, and G.B. Cutler, Jr. 1993. A constitutively activating mutation of the luteinizing hormone receptor in familial male precocious puberty. Nature. 365:654.

43. Kosugi, S., C. Van Dop, M.E. Geffner, W. Rabl, J.C. Carel, J.L. Chaussain, T. Mori, J.J. Merendino Jr., and A. Shenker. 1995. Characterization of heterogeneous mutations causing constitutive activation of the luteinizing hormone receptor in familial male precocious puberty. Hum. Mol. Genet. 4:183-188.

44. Wang, Z., E.J. Bilsky, F. Porreca, and W. Sadee. 1994. Constitutive $\mu$ opioid receptor activation as a regulatory mechanism underlying narcotic tolerance and dependence. Life Sci. 54:PL339-PL350.

45. Tiberi, M., and M.G. Caron. 1994. High agonist-independent activity is a distinguishing feature of the dopamine D1B receptor subtype. J. Biol. Chem. 269:27925-27931.

46. Benya, R.V., J.E. Mrozinski, and R.T. Jensen. 1995. Identification of a critical region within the gastrin-releasing peptide receptor (GRP-R) 3rd intracellular loop mediating $\mathrm{G}$ protein coupling. Gastroenterology. 108:951a. (Abstr.)

47. Kjelsberg, M.A., S. Cotecchia, J. Ostrowski, M.G. Caron, and R.J. Lefkowitz. 1992. Constitutive activation of the $\alpha_{1 \mathrm{~B}}$-adrenergic receptor by all amino acid substitutions at a single site. J. Biol. Chem. 267:1430-1433.

48. Huang, N.N., D.J. Wang, and L.A. Heppel. 1994. Role of adenosine $3^{\prime}, 5^{\prime}$-monophosphate-dependent protein kinase and cAMP levels in ATPdependent mitogenesis in Swiss 3 T3 cells. J. Biol. Chem. 269:548-555.

49. Ridley, A.J., and A. Hall. 1992. The small GTP-binding protein rho regulates the assembly of focal adhesions and actin stress fibers in response to growth factors. Cell. 70:389-399.

50. Miura, Y., A. Kikuchi, T. Musha, S. Kuroda, H. Yaku, T. Sasaki, and Y. Takai. 1993. Regulation of morphology by rho p21 and its inhibitory GDP/GTP exchange protein (rho GDI) in Swiss 3T3 cells. J. Biol. Chem. 268:510-515.

51. Popova, J.S., J.C. Garrison, S.G. Rhee, and M.M. Rasenick. 1997. Tubulin, $\mathrm{G}_{\mathrm{q}}$, and phosphatidylinositol 4,5-bisphosphate interact to regulate phospholipase $C \beta_{1}$ signaling. J. Biol. Chem. 272:6760-6765. 